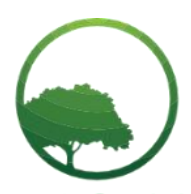

Research in Business \& Social Science

\title{
A systematic review of leadership styles, work engagement and organizational support
}

\author{
Aida Mehrad@(a), Jordi Fernández-Castro@(b), Maria Pau González Gómez de Olmedo(c) \\ a Department of Basic, Evolutionary and Educational Psychology, Universitat Autònoma de Barcelona (Bellaterra, Spain), \\ b. Grup d'Investigació en Estrès i Salut (GIES) \\ Crossref
}

c, Fundació Galatea. Barcelona (Spain)

\begin{tabular}{l} 
A R T I C L E I N F O \\
\hline Article history: \\
Received 22 May 20 \\
Received in revised form 12 June 20 \\
Accepted 18 June 20 \\
\hline Keywords: \\
Leadership Styles, Organizational \\
Support, Transformational \\
Leadership, Transactional \\
Leadership, Work Engagement \\
\hline JEL Classification: \\
M10, L20
\end{tabular}

\begin{abstract}
A B S T R A C T
Work engagement is one of the critical factors at an organization, so considering some factors such as leadership styles and organizational support is important. Lack of attention to these factors can lead to undesirable environments for workers. The purpose of this study is to conduct a systematic review based on these variables. Data for this research were gathered from databases of Web of Knowledge, psycarticles, Scopus, psycinfo, Web of Science, and Google Scholar. A total of 165 records were identified in databases. 15 records were discovered in other sources. 149 records remained after deleting duplicates. 117 of these records were examined, 52 registers excluded. 65 complete articles were chosen to be evaluated, and after 10 completed articles had been excluded, 55 studies ultimately remained for inclusion in the synthesis. Overall, leadership styles (transformational leadership and transactional leadership) and organizational support were found as two imperative organizational factors to access better outcomes at the workplace.
\end{abstract}

(C) 2020 by the authors. Licensee SSBFNET, Istanbul, Turkey. This article is an open access article distributed under the terms and conditions of the Creative Commons Attribution (CC BY) license (http://creativecommons.org/licenses/by/4.0/).

\section{Introduction}

Organizations are constantly striving to improve their structure. To achieve these ends, these organizations should be fully informed as to the human factors and other conditions which might represent efficient ways to make these improvements. A range of variables including employees' job satisfaction, the kind of work they do, their coworkers, supervisors or subordinates, their payment and incentives, and the organization's communication practices all play an important role in an organization's growth (Eslami \& Gharakhani, 2012). Thus, organizations seeking to improve outcomes must identify, classify, and assess several important variables associated with the working environment. One of the main roles of any organization is to make employees' fees secure in their jobs and provide them with suitable working conditions (Jaime, Gallo, \& Caraveo, 2012). Organizations likewise have significant obligations when it comes to ensuring employees' welfare and to protect the working environment. Moreover, the reality of each type of united system is dissimilar from one organization to another, and numerous internal and external factors are invariably involved (Moumen \& El Aoufir, 2017). Truly, human resources take on key responsibilities in every organization, tasks that are affected by different internal and external factors. Human resource departments are supported by the organization and work environment, and play a critical role in developing, realizing, and facilitating the workplace (Noordin \& Jusoff, 2009). Based on the important role of organizations and their managers at work, it is necessary to consider employees' situations, because of its leads to increased productivity, well-being, satisfaction, and engagement at work. In this regard, recognizing employees' requirements can be an effective way to manage organizations. Otherwise, a threatening work environment for employees can be created.

According to previous quantitative and qualitative studies that only focused more on outcomes of organization or workplace based on employees' performance and their presentation at work, in the current systematic review or qualitative research as a process for

* Corresponding author. ORCID ID: 0000-0003-4364-5709

(C) 2020 by the authors. Hosting by SSBFNET. Peer review under responsibility of Center for Strategic Studies in Business and Finance. https://doi.org/10.20525/ijrbs.v9i4.735 
discovery accurate styles of leadership and support from the organization after making a deep researching and conducting quantitative and qualitative studies of relevant factors; focused intensely on the role of leadership styles specifically transformational leadership and transactional leadership, and organizational support on work engagement, and determined their interrelation as the main objective of this study. To catch up on this purpose, the researchers of the study applied a systematic review method as a research methodology to filling the gap of earlier studies and making a brilliant role of leadership from managers and leaders among employees, also showing the important role of organization support on employees' work engagement.

The remembrance of the present study is structured as follows. The next segment provides a literature review that focused on work engagement, leadership styles, and organizational support. The third section presents the methodology and systematic research. The fourth section focuses on results and a summary of research reports. And the fifth section explains the discussion; finally, conclusions and acknowledgment of the study are presented.

\section{Literature Review}

\section{Theoretical and Empirical Studies}

There are various theoretical and empirical studies that have been focused on Work Engagement, Organizational Support, and Leadership Styles. Based on the model of work engagement that has been proposed by Bakker and Demerouti (2008), work engagement assumed as a positive, sufficient, and motivational job-related state of mind categorized through vigor, dedication, and absorption. Vigor is situated characterized by high levels of energy, mental resilience while working, determination when faced with problems, and a willingness to invest effort in one's work. The dedication also refers to a sense of stimulation, pride, significance, enthusiasm, and challenge at the workplace. Finally, absorption is the feeling of being pleased, fully concentrated, and deeply engrossed in one's work, and it goes along with trouble detaching oneself from work.

Additionally, in the empirical studies about work engagement has been explained that this factor plays a considerable role in employees' performance and behavior; engaged employees tend to display greater knowledge sharing, creativity, proactivity, and adaptability (Eldor, 2017). Also, work engagement has increasingly taken on the status of a legitimate construct among academic scholars (Strom, Sears, \& Kelly, 2014). This factor has been defined as one of the organizational factors that are in turn affected by various other variables. In other words, the presence of one factor or another can improve or worsen employee engagement. Among the many factors, the role of the organization and the manager are of special importance and should be considered as some of the foremost aspects that influence engagement. Engaged employees, in turn, influence an organization's outcomes, customer satisfaction, retention rates, productivity, and profitability (Markos \& Sridevi, 2010; Wang, 2015). Therefore, it is important to seek out factors that may be effective in furthering a range of organizational behaviors such as work engagement among employees within their working environment (Ahmad, Ahmad \& Ali Shah, 2010). Certain organizational features exert a remarkable influence on employees' work engagement. Organizations must focus on creating a work environment that is supportive of employees and on keeping them motivated and positive, not just about their occupations but also about the organization as a whole (Strom et al., 2014). According to a study by Lee, Idris, Delfabbro, and Paul (2017), employees' work engagement is influenced by different organizational factors, such as leadership style, organizational culture, and empowering a leader to have a critical effect on work engagement via work meaningfulness. In broad terms, the purpose of this study emphasized the important role of organization and leaders and their strategies for supporting and managing employees.

Based on the theoretical study of leadership styles, the social learning theory explained about employees acquire values, emotions, attitudes, and behaviors from leaders. Moreover, leadership styles play an indispensable role in the workplace (Xinxin, Baoguo, \& Yongxing, 2018). In addition, in the behavioral approach has been reported all styles of leadership have a direct relationship with employees' responses and organizational behavior at the workplace (Bandura \& Schunk, 2000). A study by Blomme, Kodden, and Beasley-Suffolk (2015) specified that transactional leadership involves the stimulation of needs, competencies, and ambitions of the followers, challenging followers intelligently, and exerting charismatic and inspiring leadership, through which followers can be stimulated energetically. Transformational leadership also provides followers with challenges, whereby employees are stimulated to attain goals, perfect their skills, and achieve mastery. In this regard, leaders who treat employees with respect, display concern, communicate in a friendly manner, and who set uniform standards for action are likely to stimulate high levels of employee work engagement.

In the empirical studies likewise leadership styles introduced as external factors and affect employees' feelings and change their attitudes toward their jobs and their performance. Leadership is mostly directed towards people and social communications. Specifically, leadership is one of the main factors that affect people's understandings of organizational policies (Saleem, 2015). Leadership can be an interpersonal strategy wherein a leader makes an effort to find out followers' potential requirements and satisfy them. In this way, the purposes of an organization can be achieved by influencing followers. Leadership styles likewise regulate purpose, direction, and employee programs at an organization. Leadership styles have been defined as a series of managerial tendencies, behaviors, and abilities based on personal and organizational standards. Hsieh and Wang (2015) have observed that leadership represents a critical factor in ensuring organizational sustainability in today's work environment. Furthermore, it is increasingly evident that in the twenty-first-century leadership must come from a new and more contemporary type of leader. Meanwhile, managers can promote positive employee association via effective leadership. Moreover, leadership is one of the single 
biggest elements that contribute to employee work engagement. Additionally, the results of positive psychology and positive organizational behavior studies indicate that leadership is extremely important for generating encouraging well-being at the workplace. It also has a considerable effect on employees' reactions and increases their intrinsic motivation. Styles of leadership include authoritarian, paternalistic, democratic, laissez-faire, transactional, and transformational. The authoritarian style is exercised by the assertive leader that tries to attract employees' attention to his or her orders, while the paternalistic style also is associated with the kind of powerful leader who demands that everyone should respect him or her. Meanwhile, the democratic style is embraced by leaders that endeavor to accomplish their goals with the direct participation of others. The laissez-faire style refers to leaders who help all individuals work together for the common good (Abu Mansor, Waib, Mohamed, \& Ishak Md Shah, 2012). Transformational leadership and transactional leadership are the two main and most effective organizational leadership styles in the workplace (Dimitrov, 2015; Mitonga-Monga \& Veronica, 2017). Transactional leadership is characterized by a relationship of exchange between the leader and employee, in which each party pursues his or her respective self-interests. Each party's interests are met by clarifying the employee responsibilities, the leader's expectations, and the benefits of compliance. However, transformational leadership revolves around a leader's ability to interact with, understand and support employees beyond the standard employment exchange. Transformational leaders may take on roles such as that of facilitator, mentor, and innovator, depending on situational conditions and the individual characteristics of a given leader. Transformational leadership attempts to align employee values, beliefs, and attitudes with the collective interest of the organization, creating a workforce committed to and working toward a singular vision (Strom et al., 2014). According to Henker, Sonnentag, and Unger (2015), transformational leadership includes behaviors that encourage employees to take on a more comprehensive view of how they do their work and challenge them to adopt new approaches. Transformational leadership has been found to involve six key behaviors, namely, providing intellectual stimulation, articulating a vision, providing appropriate model, fostering the acceptance of group goals, expecting a high performance, and providing individualized support that improves employees' ways of working (Hayati, Charkhabi, \& Naami, 2014). A low degree of transformational leadership leads to a higher degree of transactional leadership at the workplace; also, it can be threatening for the work environment (Strom et al., 2014). Furthermore, leaders should know different styles of leadership for the conditions at a given organization (Mitonga-Monga \& Veronica, 2017).

Organizational support was determined as one of the main factors at the organization that should be well-thought-out about it. Certainly, presence and perceived organizational support meaningfully predicted the task performance, optional performance, and convinced future career aspirations of employees in the work environment (Duyar \& Aydin, 2012). The organizational factor is one of the critical factors at the workplace that should be a subject of growing consideration. Indeed, perceiving organizational support meaningfully predicted the task performance, optional performance, and certain future career aspirations of employees in the work environment. Based on Harris, Li, Boswell, Zhang, XA, and Xie (2014), organizational support is one of the critical factors that can predict the performance of a leader; it also affects empowering leadership at the place of work. The support offered by leaders and organizations and organization exerts a great influence on the level of performance and outcomes of a workplace (Korzynski, 2015). In other words, one of the main managerial tasks is organizational support, which should be considered carefully (Corin \& Bjork, 2016). A study by Manning (2016) found that organizational support derived from transformational and transactional leadership styles can have a positive impact on work engagement. In truth, this organizational factor acts as a positive motivating force and increases constructive attitudes and the engagement of employees (Al Mehrzi \& Singh, 2016).

\section{Methodology}

In the present systematic review, databases were systematically searched for eligible studies and the data were derived from the databases [ISI] Web of Knowledge, PsycARTICLES, Scopus, PsycINFO, Web of Science, and Google Scholar. Based on this review, the researcher selected 55 articles from amongst 165 papers that were uncovered in the databases and were somehow related to the object of study: "leadership styles, work engagement, and organizational support".

The results of the search were obtained from English-language journal articles published from 2009-2018 in peer-reviewed journals. For the initial search, the search terms were as follows: a) "leadership", b) "leadership styles", c) "work engagement", d) "transformational leadership", e) "transactional leadership", and f) "organizational support". Each of the searches consisted of two of these keywords along with "OR" and "AND": ((Leadership) OR (Leadership Styles) OR (Transformational Leadership) OR (Transactional Leadership) AND (Engagement) AND (Work Engagement) AND (Organizational Support)). Besides, the study used a series of inclusion criteria to screen papers for the review.

These factors included: English language, years of papers publication $>2009$, papers that had been published in peer-reviewed journals and dealt with leadership styles (transformational and transactional), work engagement, organizational support as the main aim of the study.

"Figure 1" displays the PRISMA based on qualitative and quantitative papers that were obtained based on the research objective. As displayed below, a total of only 55 of the original 165 articles were ultimately included in the investigation. 


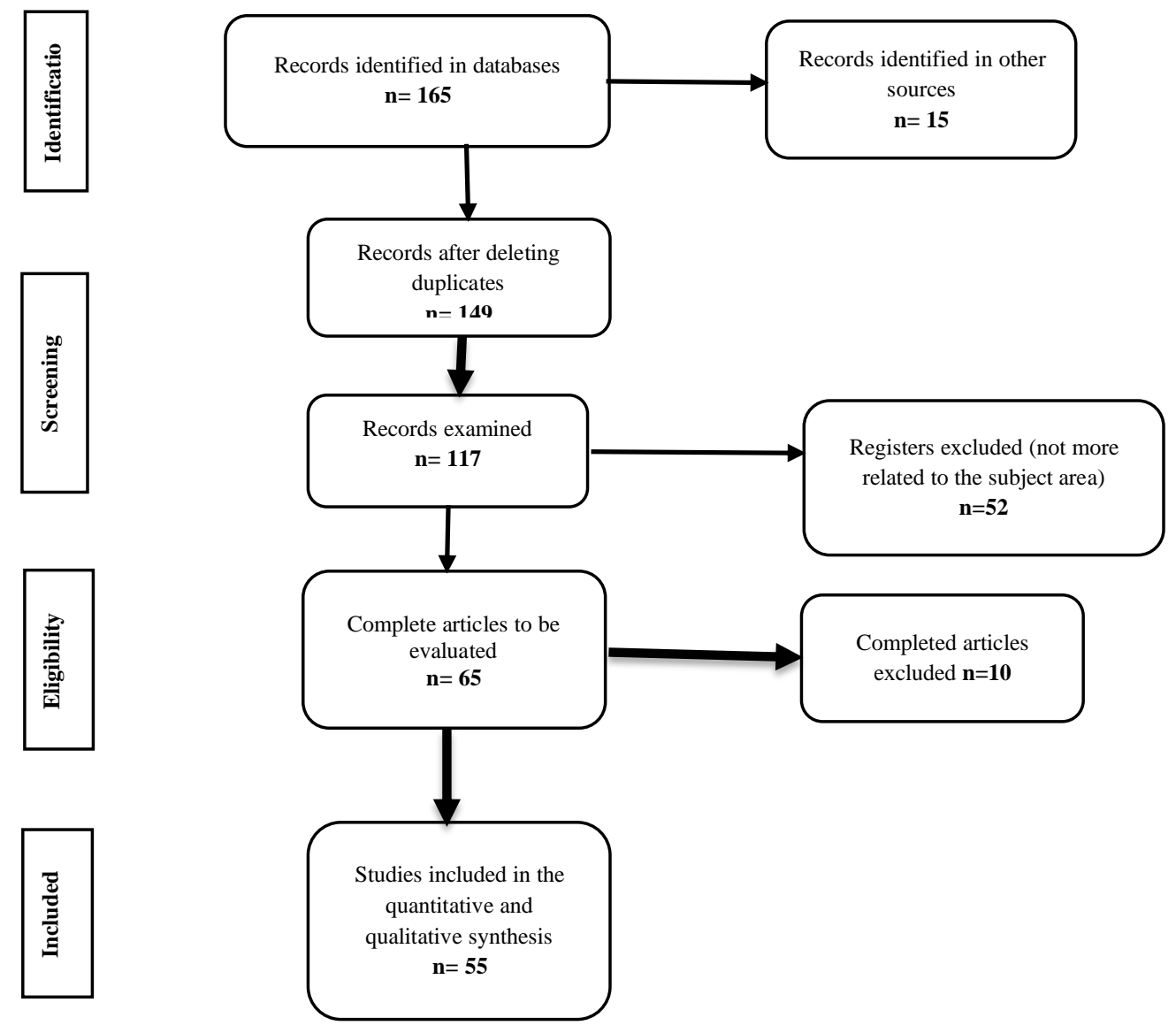

\section{Results}

As illustrated in PRISMA, the present study ultimately included a total of 55 articles. Table 1 shows a summary of the researchers' findings with regard to leadership styles, work engagement, and organizational support. The articles that have been reviewed by the researchers were analyzed in quantitative and qualitative terms based on leadership styles, work engagement, and organizational support.

Table 1: Summary of Researchers' Report

\begin{tabular}{|c|c|c|}
\hline Author/Year & Study Purpose & Subjects \\
\hline $\begin{array}{l}\text { Bakker \& Demerouti } \\
(2008)\end{array}$ & $\begin{array}{l}\text { Focused on the importance of work engagement and its aspects, it also explained } \\
\text { that engaged workers are more creative, fruitful, and more willing to go the extra } \\
\text { mile. }\end{array}$ & $\begin{array}{l}\text { Workers, } \\
\text { quantitative and qualitative } \\
\text { study }\end{array}$ \\
\hline $\begin{array}{l}\text { Noordin \& Jusoff } \\
(2009)\end{array}$ & $\begin{array}{l}\text { Focused on the attitude of employees and organizational factors that impact } \\
\text { employees' beliefs about their job. }\end{array}$ & $\begin{array}{l}360 \text { Employees, } \\
\text { quantitative study }\end{array}$ \\
\hline Ahmad et al. (2010) & $\begin{array}{l}\text { Reported there are different organizational factors that make considerable } \\
\text { contributions to employees' performance at the workplace. }\end{array}$ & $\begin{array}{l}310 \text { Pakistanis workers, } \\
\text { quantitative study }\end{array}$ \\
\hline $\begin{array}{l}\text { Hanson } \\
(2010)\end{array} \quad \& \quad$ Ward & Examined the relationship between leadership styles and work engagement. & Singaporean Teachers \\
\hline Cobzaru (2010) & $\begin{array}{l}\text { Considered the important role of work engagement amongst employees at a private } \\
\text { university. }\end{array}$ & University employees \\
\hline $\begin{array}{l}\text { Markos \& Sridevi } \\
(2010)\end{array}$ & $\begin{array}{l}\text { Explored the relationship between corporate social responsibility, employee } \\
\text { engagement, and organizational performance in mobile telecommunication } \\
\text { companies. }\end{array}$ & $\begin{array}{l}350 \text { Jordanian Employees, } \\
\text { quantitative study }\end{array}$ \\
\hline $\begin{array}{l}\text { Zacher } \quad \& \quad \text { Winter } \\
(2011)\end{array}$ & $\begin{array}{l}\text { Examining the extent to which perceived organizational, supervisor, and co-worker } \\
\text { support for eldercare workers reduces caregivers' strain and weakens the relationship } \\
\text { between eldercare demands and strain. }\end{array}$ & $\begin{array}{l}100 \text { Employees, } \\
\text { Quantitative study }\end{array}$ \\
\hline
\end{tabular}




\begin{tabular}{|c|c|c|}
\hline Ghafoor et al. (2011) & $\begin{array}{l}\text { Examining the relationship between transformational leadership, employee } \\
\text { engagement, and employee performance. }\end{array}$ & $\begin{array}{l}270 \text { Employees and } \\
\text { Managers, } \\
\text { quantitative study }\end{array}$ \\
\hline $\begin{array}{l}\text { Zhang } \\
(2011)\end{array} \quad \& \quad$ Bartol & $\begin{array}{l}\text { It considers effective factors for innovating a high level of performance that drives } \\
\text { from team psychological empowerment. }\end{array}$ & Qualitative study \\
\hline $\begin{array}{l}\text { Abu Mansor et al. } \\
(2012)\end{array}$ & $\begin{array}{l}\text { Examining the relationship between management styles practiced by managers and } \\
\text { employees' well-being at an international bank in Malaysia. }\end{array}$ & $\begin{array}{l}47 \text { Respondents from the } \\
\text { bank, } \\
\text { Quantitative study }\end{array}$ \\
\hline Duyar \& Normore (2012) & $\begin{array}{l}\text { Focused on the imperative role of leadership and management at the } \\
\text { workplace. }\end{array}$ & Qualitative study \\
\hline $\begin{array}{l}\text { Eslami \& Gharakhani } \\
(2012)\end{array}$ & Examining the effects of job satisfaction on organizational commitments. & $\begin{array}{l}280 \text { Iranian employees, } \\
\text { quantitative study }\end{array}$ \\
\hline Jaime et al. (2012) & $\begin{array}{l}\text { Examining the role of the mental health integrity of clinical staff at a } \\
\text { psychiatric hospital, associated with burn-out and toxic management. }\end{array}$ & Staff at a psychiatric hospital \\
\hline Ghadi et al. (2013) & $\begin{array}{l}\text { Examining the relationship between transformational leadership and work } \\
\text { engagement through the mediating role of meaning in work. }\end{array}$ & $\begin{array}{l}530 \text { Employees, } \\
\text { quantitative study }\end{array}$ \\
\hline Strom et al. (2014) & $\begin{array}{l}\text { Examining both transactional and transformational leadership styles and } \\
\text { their role as moderators in the relationship between organizational justice } \\
\text { and work engagement. }\end{array}$ & $\begin{array}{l}348 \text { Respondents, } \\
\text { quantitative study }\end{array}$ \\
\hline $\begin{array}{l}\text { Caesens \& Stinglhamber } \\
\text { (2014) }\end{array}$ & $\begin{array}{l}\text { Investigating the relationship between perceived organizational support and } \\
\text { work engagement. }\end{array}$ & $\begin{array}{l}265 \text { Employees and } 112 \\
\text { Supportive of the effectiveness, } \\
\text { quantitative study }\end{array}$ \\
\hline Hayati et al. (2014) & $\begin{array}{l}\text { To determine the effects of transformational leadership and its components } \\
\text { on work engagement among hospital nurses. }\end{array}$ & $\begin{array}{l}240 \text { Nurses, } \\
\text { quantitative study }\end{array}$ \\
\hline Giray \& Şahin (2014) & $\begin{array}{l}\text { To investigate the mediating role of perceived organizational support on the } \\
\text { relationship between leadership styles (paternalistic, participative and } \\
\text { authoritarian leadership) and organizational variables (effective } \\
\text { commitment and intention to leave). }\end{array}$ & $\begin{array}{l}341 \text { Participants, } \\
\text { quantitative study }\end{array}$ \\
\hline Harris et al. (2014) & $\begin{array}{l}\text { To focus on empowering leadership, creativity, and adjustment in the } \\
\text { socialization context. }\end{array}$ & Qualitative study \\
\hline
\end{tabular}




\begin{tabular}{|c|c|c|}
\hline Table: Cont'd & & \\
\hline Zone (2014) & $\begin{array}{l}\text { To explore the relationship between perceived organizational } \\
\text { support, job satisfaction, and years of online teaching } \\
\text { experience with work engagement. }\end{array}$ & $\begin{array}{l}\text { Undergraduate assistant } \\
\text { faculty members (thesis), } \\
\text { quantitative study }\end{array}$ \\
\hline Blomme et al. (2015) & $\begin{array}{l}\text { To focus on leadership theories and the concept of work } \\
\text { engagement. }\end{array}$ & Qualitative study \\
\hline Hsieh \& Wang (2015) & $\begin{array}{l}\text { To examine the influence of authentic leadership on employee } \\
\text { trust and employee work engagement from the dyadic } \\
\text { supervisor-employee viewpoint. }\end{array}$ & $\begin{array}{l}345 \text { Taiwanese employees } \\
\text { in } 36 \text { companies, } \\
\text { quantitative study }\end{array}$ \\
\hline Popli \& Rizvi (2015) & $\begin{array}{l}\text { To explore the relationship between leadership, employee } \\
\text { engagement, and service orientation. }\end{array}$ & $\begin{array}{l}106 \text { Indian Managers } \\
\text { in the private } \\
\text { organizations, } \\
\text { quantitative study }\end{array}$ \\
\hline Saleem (2015) & $\begin{array}{l}\text { Focused on transformational leadership, job satisfaction, } \\
\text { organizational commitment and turnover intentions: the direct } \\
\text { effects among bank representatives. }\end{array}$ & $\begin{array}{l}181 \text { Bank staff, } \\
\text { quantitative study }\end{array}$ \\
\hline Carasco-Saul et al. (2015) & Considers leadership and employee engagement. & Qualitative study \\
\hline $\begin{array}{l}\text { Gözükaraa \& Simsek } \\
\text { (2015) }\end{array}$ & $\begin{array}{l}\text { Examines the effect of transformational leadership on the work } \\
\text { engagement of academicians through job autonomy. }\end{array}$ & $\begin{array}{l}101 \text { Academic staff, } \\
\text { quantitative study }\end{array}$ \\
\hline Dimitrov (2015) & $\begin{array}{l}\text { To explore the way leadership influences an organization to } \\
\text { become humane through its features and behaviors. }\end{array}$ & $\begin{array}{l}17 \text { Participants, } \\
\text { quantitative study }\end{array}$ \\
\hline Korzynski (2015) & $\begin{array}{l}\text { To examine the role of online networks in employee } \\
\text { engagement and to analyze the factors influencing leaders' } \\
\text { involvement in online social networking. }\end{array}$ & $\begin{array}{l}\text { Team leaders, managers and } \\
\text { directors in US companies } \\
\text { quantitative study }\end{array}$ \\
\hline Henker et al. (2015) & $\begin{array}{l}\text { To investigate the processes underlying the relationship } \\
\text { between transformational leadership and employee creativity. }\end{array}$ & $\begin{array}{l}279 \text { Employees, } \\
\text { quantitative study }\end{array}$ \\
\hline
\end{tabular}

Wang (2015) investigate the benefits of a proactive employee
personality, role of engagement, team proactivity composition,
and perceived organizational support.

\begin{tabular}{lll}
\hline Meng \& Xiao (2015) & $\begin{array}{l}\text { Focused on the influence of spiritual leadership on hospitality } \\
\text { industry employee engagement. }\end{array}$ & Employees
\end{tabular}

\begin{tabular}{|c|c|c|}
\hline $\begin{array}{l}\text { Al Mehrzi, \& Singh } \\
(2016)\end{array}$ & $\begin{array}{l}\text { Focused on framework through which to understand, predict } \\
\text { and control factors affecting employee engagement in the } \\
\text { public sector in the United Arab Emirates (UAE). }\end{array}$ & Qualitative study \\
\hline Manning (2016) & $\begin{array}{l}\text { To evaluate the influence of nurse manager leadership style } \\
\text { factors on staff nurse work engagement. }\end{array}$ & $\begin{array}{l}441 \text { Nurses, } \\
\text { quantitative study }\end{array}$ \\
\hline Jeong et al. (2016) & $\begin{array}{l}\text { To examine the relationships between teachers' work } \\
\text { engagement and their professionalism and openness to change } \\
\text { and the moderating role of the transformational leadership of } \\
\text { principals in explaining these relationships. }\end{array}$ & $\begin{array}{l}1,886 \text { Teachers from } 59 \text { schools } \\
\text { in South Korea, } \\
\text { quantitative study }\end{array}$ \\
\hline Schmitt et al. (2016) & $\begin{array}{l}\text { Explores the role of work engagement as an affective- } \\
\text { motivational mechanism through which transformational } \\
\text { leadership may relate to proactive behaviour. }\end{array}$ & $\begin{array}{l}148 \text { Employees in the } \\
\text { Netherlands, } \\
\text { quantitative study }\end{array}$ \\
\hline $\begin{array}{l}\text { Engelbrecht et al. } \\
(2016)\end{array}$ & $\begin{array}{l}\text { To investigate how leader integrity and ethical leadership can } \\
\text { influence trust in the leader and employee work engagement. }\end{array}$ & $\begin{array}{l}204 \text { Employees, } \\
\text { quantitative study }\end{array}$ \\
\hline
\end{tabular}




\begin{tabular}{|c|c|c|}
\hline Shantz et al. (2016) & $\begin{array}{l}\text { To explore the relationship between work engagement } \\
\text { affective commitment, and turnover intentions. }\end{array}$ & Qualitative study \\
\hline Bass et al. (2016) & Focused on work engagement and transformational leadership. & $\begin{array}{l}728 \text { Employees, } \\
\text { quantitative study }\end{array}$ \\
\hline Zhu et al. (2016) & $\begin{array}{l}\text { Examines whether follower characteristics moderate the } \\
\text { relationship between transformational leadership and follower } \\
\text { work engagement. }\end{array}$ & $\begin{array}{l}140 \text { Followers and } 48 \\
\text { supervisors, } \\
\text { quantitative study }\end{array}$ \\
\hline $\begin{array}{l}\text { Breevaart et al. } \\
(2016)\end{array}$ & $\begin{array}{l}\text { To examine relation between transformational leadership } \\
\text { behaviours, employee self-leadership strategies, employee work } \\
\text { engagement, and job performance. }\end{array}$ & $\begin{array}{l}57 \text { Leader employees, } \\
\text { quantitative study }\end{array}$ \\
\hline Eldor (2017) & $\begin{array}{l}\text { Focused on the positive role of organisational politics in the } \\
\text { relationship between employee engagement and performance at } \\
\text { work. }\end{array}$ & $\begin{array}{l}253 \text { High-tech } \\
\text { employees and their } \\
\text { supervisors in Israel, } \\
\text { quantitative study }\end{array}$ \\
\hline $\begin{array}{l}\text { Goswami et al. } \\
(2016)\end{array}$ & $\begin{array}{l}\text { To examine work engagement, job performance, and } \\
\text { organizational citizenship behaviours (OCBs) with the } \\
\text { moderating effect of transformational leadership style on the } \\
\text { relationship between leaders' use of positive humour and } \\
\text { subordinate's positive affect at work. }\end{array}$ & $\begin{array}{l}235 \quad \text { Full-time } \\
\text { employees, } \\
\text { quantitative study }\end{array}$ \\
\hline $\begin{array}{l}\text { Corin \& Björk } \\
(2016)\end{array}$ & $\begin{array}{l}\text { Focused on job demands and job resources in human service } \\
\text { managerial work an external assessment through work content } \\
\text { analysis. }\end{array}$ & $\begin{array}{l}\text { Different groups of } \\
\text { managers }\end{array}$ \\
\hline $\mathrm{Ni}(2016)$ & $\begin{array}{l}\text { Considers the relationship between leadership style and } \\
\text { management performance by taking employee engagement and } \\
\text { psychological empowerment as intermediary variables. }\end{array}$ & $\begin{array}{l}342 \text { Participants in } 35 \\
\text { municipal power supply } \\
\text { companies }\end{array}$ \\
\hline $\begin{array}{l}\text { Lewis \& } \\
\text { Cunningham } \\
(2016)\end{array}$ & To explore self-motivators amongst children & $\begin{array}{l}120 \text { Nurses Experiment } \\
\text { study }\end{array}$ \\
\hline $\begin{array}{l}\text { Bandura \& Schunk } \\
\text { (2000) }\end{array}$ & Focused on leadership styles and work engagement. & $\begin{array}{l}36 \text { Children, Experimental } \\
\text { study }\end{array}$ \\
\hline $\begin{array}{l}\text { Mitonga-Monga \& } \\
\text { Veronica (2017) }\end{array}$ & $\begin{array}{l}\text { Focused on a conditional process model linking perceived } \\
\text { transformational nurse leadership to nurse staff burnout and } \\
\text { engagement via important work environment characteristics. }\end{array}$ & 200 Employees (DRS) \\
\hline
\end{tabular}

Lee et al. (2017) To explore the linkages between hierarchical culture, 134 Employees empowering leadership, employees' work engagement, and work meaningfulness as a mediator.

$\& 28$ teams

\begin{tabular}{lll}
\hline Hempfling (2017) & $\begin{array}{l}\text { To explore happiness, work engagement, and perception of } \\
\text { organizational support of student affairs professionals. }\end{array}$ & $\begin{array}{l}\text { American Professionals in the } \\
\text { College }\end{array}$ \\
& Personnel Association
\end{tabular}

Gillet et al. (2017) To examine organizational support, job resources, soldiers' Soldiers motivational profiles, work engagement, and affect. 


$\begin{aligned} & \text { Moumen \& } \\ & \text { Aoufir (2017) }\end{aligned}$
$\begin{aligned} & \text { To discuss some empirical studies that have documented the } \\ & \text { experiences of organizations. }\end{aligned}$ $\begin{aligned} & \begin{array}{l}\text { Moroccan companies, } \\ \text { empirical study }\end{array}\end{aligned}$

Aoufir (2017) experiences of organizations. empirical study

Xiang et al. (2017) To focus on leadership as one the main organizational factor Qualitative Study at the workplace and its relationship with work engagement.

Yongxing et al. To examine whether the relationship between work 1049 Employees

(2017) engagement and objective task performance is moderated by perceived organizational support (POS).

\begin{tabular}{llll}
\hline Xinxin et al. (2018) & $\begin{array}{l}\text { To explore how and when leader work engagement trickles } \\
\text { down to followers. }\end{array}$ & $\begin{array}{l}707 \text { Employees } \\
\text { teams }\end{array}$ & in
\end{tabular}
down to followers.

224

Enwereuzor et al. To expand the existing literature on transformational

(2018) leadership and work engagement by considering the moderating role of P-J fit.

Participants

According to the results of this systematic review, previous studies in different workplaces and countries, and the researchers who have conducted them specifically recommend transformational and transactional leadership. They also say that organizational support makes an effective contribution to performance, attitude, the organizational behavior of employees, and their engagement. These realities should be explained or introduced more comprehensively to managers, leaders, and the heads of various workplaces. The current study represents an attempt to recognize the meaningful role of transformational and transactional styles, and their different and various segments of the work environment. The study also focuses on organizational support, which derives from the manager and workplace and improves and motivates employees' engagement at work.

\section{Discussion}

Based on the important role of leadership and purpose of the present study, some investigations focused on the relationship between leadership and engagement, so in continue discussed them comprehensively. Leaders exert an influence on employee optimism, organizational commitment, collective identification, and cooperation. Efficiency and innovation adaptation mediate the relation between leadership and human capital. Leadership has an impact on organizational and other human behavior (Dimitrov, 2015). In this regard, Meng and Xiao (2015) explained that employees hope to do interesting work and obtain good rewards. In effect, the presence of engagement among employees can grow this desire, but there needs to be some effective organizational factors in place to lead to engagement. Leadership can lead to engagement and improved outcomes at the workplace if it offered correctly. In the research based on engagement and leadership, Hanson and Ward (2010) focused on teachers' engagement and leadership in Singapore schools. They explained that leaders need more knowledge about the leadership strategy if they are to satisfy teachers and increase their engagement.

Elsewhere, Ghafoor, Qureshi, Khan, and Hijazi (2011) explained that there is a significant relationship between transformational leadership and work engagement. Furthermore, applying the precise style of leadership is a critical factor in encouraging work engagement (Zhang \& Bartol, 2011; Hsieh \& Wang, 2015). According to Ghadi, Fernando, and Caputi (2013), transformational leadership makes a considerable contribution to employees' attitudes and their motivation. This factor is the main organizational factor that increases the level of engagement and satisfaction amongst employees. Hayati et al. (2014) explained that transformational leadership has a positive influence on employees' behaviors. Transformational leaders transfer their interest and high level of power to their assistants. A lower degree of transactional leadership causes indecision about one's social self in the context of work, and this state of indecision incites an employee's deepened desire to seek justice-related information. In general, leadership influences 
employees' satisfaction and their work engagement at the workplace (Dimitrov, 2015). The relationship between leaders and employees is worthy of special consideration (Carasco-Saul, Kim, \& Kim, 2015). Employees' attitudes and behaviors are directly influenced by leadership styles at the organization. Transformational leadership creates and fosters an environment that builds trust and confidence, and it encourages employees' development along with a shared vision for the organization, while transactional leadership lays the foundations of a more transformational leadership style (Popli \& Rizvi, 2015). The leader should recognize the conditions and produce an appropriate reaction (Blomme et al., 2015). In parallel with previous studies, Gözükaraa and Simsek (2015) described that transformational leadership makes a considerable contribution to improving work engagement.

In 2016, Jeong, Hsiao, Song, Kim, Junhee, and Bae in Korea studied transformational leadership and work engagement amongst teachers. The researchers explained that transformational leadership does not have a direct association with engagement, but it moderated positively the relationship between work engagement and openness. Additionally, transformational leadership plays a negative moderation role in the relationship between work engagement and professionalism. In a study by Schmitt, Den Hartog, and Belschak (2016), the researchers reported that transformational leadership has a positive relationship with work engagement. This, in turn, leads to improved performance and more positive attitudes amongst employees. Similarly, Ni (2016) has emphasized improving leadership style to increase the presence and engagement of staff. A study of Goswami, Nair, Beehr, and Grossenbacher (2016) examined the role of emotions as a mediator and transformational leadership as a moderating force on the leader's sense of humor and employees' engagement. The researchers explained that transformational leadership creates a positive relationship between a leader's sense of humor and employees' engagement.

In parallel with previous studies, Bass, Cigularov, Chen, Henry, Tomazic, and Li (2016) clarified that transformational leadership has a positive association with employees' work engagement, and it can control employees' behavior when they are confronted with contexts of violence. A study by Zhu, Avolio, and Walumbwa (2016) focused on the role of followers' characteristics as a moderator of the association between transformational leadership and follower work engagement. These investigators explained that transformational leadership has a positive impact on work engagement when followers display positive characteristics. They believed that transformational leadership was positively associated with higher levels of followers' psychological meaningfulness, psychological safety, and psychological availability, which caused higher levels of engagement among employees. A seminal study in this area is the work of Breevaart, Bakker, Demerouti, and Darks (2016), which found that employees were more engaged in their work when their leaders used more transformational leadership behaviors. This study found that transformational leadership behaviors were an effective factor for employees when they need leadership. Also, a study conducted by Lewis and Cunningham (2016) showed that there is a positive relationship between transformational leadership and work engagement. In 2018, Enwereuzor, Ugwu, and Eze explained that transformational leadership was one of the main factors of leadership style has a positive relationship with work engagement; Additionally, this positive relation is more pronounced among nurses who have high person-job fit than with those who have low person-job fit. In truth, the person-job fit was found to be an important factor within the organization and worthy of consideration. All these studies have shown that type of leadership has a considerable role in the amount of engagement and creates a convenient atmosphere for working and feeling well. With consideration to the aim of this study which focused on the important role of organizational support and its relationship with work engagement, some studies explored these relations, in continued discussion in detail. Organizational support includes the type of support that is present in all the employees' interactions with organizational agents such as leaders.

The measurement of organizational support reflects employees' beliefs concerning the extent to which this organization they work for values their contributions and cares about their well-being. This factor also can produce a feeling of responsibility to care about the organization's welfare and to help the organization reach goals based on the reciprocity norm (Yongxing, Hongfei, Baoguo, \& Lei, 2017). In parallel with this study, Shantz, Alfes, and Latham (2016) reported that organizational support moderates the relationship between work engagement and turnover intentions and deviant behaviors. According to Gillet, Becker, Lafrenière, Huart, and Fouquereau (2017), organizational support and work engagement are two main factors that should be improved and considered by leaders and considered in the workplace. Similarly, Hempfling (2017) explained that organizational support has a direct relation with work engagement and individuals who received support show a high level of engagement. The study by Caesens and Stinglhamber (2014) clarified that there is a significant relationship between work engagement and organizational support. Perceiving a high degree of organizational support automatically increased the amount of work engagement (Zone, 2014). Overall, perceived organizational support is beneficial for employees' work engagement (Zacher \& Winter, 2011). Also, the key significance of leadership styles and organizational support has been considered in the current study that has been reported to continue. Giray and Şahin (2014) stated that there were significant relationships between organizational support and leadership styles in the workplace.

Earlier studies in the field of work engagement concentrated on different factors that influence work engagement and that might decrease the level of this organizational factor amongst employees. Recent studies have found that organizational support is one of the main managerial tasks that should be considered carefully (Corin \& Bjork, 2016). Support usually comes from the leader and the work environment and plays a meaningful role in employees' attitudes about their work. Indeed, there are many factors associated with a low level of work engagement among employees that influence their performance. Thus, determining what factors are effective amongst employees can be valuable for the organization. Undoubtedly, the presence of these factors makes a considerable contribution to engagement. Leadership has been identified as one of the key factors affecting work engagement. The various kinds of leadership can have differing effects on employees' engagement, and this can lead to different kinds of organizational outcomes. 
In general, employees who are not engaged will experience major changes in their performance and behavior (Markos \& Sridevi, 2010). The type of leadership and organizational support are two main organizational factors related to work engagement and to increase its level at the workplace (Xiang, Chen, \& Zhao, 2017). A study by Cobzaru (2010) established that amongst employees, work engagement and the various domains that make it up (vigor, dedication, and absorption) play a vital role in employees' position at the workplace. In line with these studies, Engelbrecht, Heine, and Mahembe (2016) explained that engaged employees are more creative, enjoy their work more, and are better well-organized and more committed to their work. In this regard, the current systematic review attributes a very valuable role in engagement amongst employees.

\section{Conclusions}

This systematic review has synthesized literature that derived from different interventions and approaches to support work engagement at the workplace based on leadership styles and organizational support, all to achieve better outcomes at the workplace. Employees often base their view of their position, rights, responsibilities, organizational behavior, and feelings toward their jobs on the type of leadership styles and organizational support that they may find in various kinds of workplace situations. Meanwhile, the framework used in this systematic review for work engagement, organizational support, and leadership styles may be valuable not only for documenting the lessons of prior studies but also for developing and evaluating these practices and their impact on different types of workplaces and communities. Overall, these guidelines could help address the low level of engagement amongst employees and help achieve a high level of performance and improved outcomes.

Recognizing the different factors that improve and support the presence and engagement of employees at the workplace can be of great academic and practical value. However, more specific investigations are needed to focus on these issues. Some have been done in the past, while others might wait in the future. The overall point of this systematic review is focused on the important role of work engagement amongst employees, a factor that is influenced and, in some cases, improved by transformational leadership, transactional leadership, and organizational support.

\section{Acknowledgement}

This research supported by the Ministerio de Economía y Competitividad (Spain)/FEDER. PSI2016-76411-R.

\section{References}

Abu Mansor, N. N., Waib, C. M., \& Ishak Md Shah, M. A. (2012). The Relationship between Management Style and Employees' Well-Being: A Case of Non-Managerial Staffs. Social and Behavioral Sciences, 40 (2012), 521-529. https://doi.org/10.1016/j.sbspro.2012.03.225

Al Mehrzi, N., \& Singh, S. K. (2016). Competing through employee engagement: a proposed framework. International Journal of Productivity and Performance Management, 65 (6), 831-843, https://doi.org/10.1108/IJPPM-02-2016-0037

Ahmad, H., Ahmad, K. \& Ali Shah, I. (2010). Relationship between job satisfaction, job performance attitude towards work and organizational commitment. European Journal of Social Science, 18(2), 257-267.

Bakker, A. B., \& Demerouti, E. (2008). Towards a model of work engagement. Career Development International, 13(3), $209-223$. https://doi.org/10.1108/13620430810870476

Bandura, A., \& Schunk, D. H. (2000). Cultivating competence, self-efficacy and intrinsic interest through proximal self-motivation. Journal of Personality and Social Psychology, 41(3), 586-598. http://dx.doi.org/10.1037/0022-3514.41.3.586

Bass, B. I., Cigularov, K. P., Chen, P.Y., Henry, K.L., Tomazic, R.G., \& Li, Y.Q. (2016). The Effects of Student Violence Against School Employees on Employee Burnout and Work Engagement: The Roles of Perceived School Unsafety and Transformational Leadership. International Journal of Stress Management, 23 (3), 318-336. https://doi.org/10.1037/str0000011

Blomme, R. J., Kodden, B., \& Beasley-Suffolk, A. (2015). Leadership theories and the concept of work engagement: Creating a conceptual framework for management implications and research. Journal of Management \& Organization, 21(2), 125-144. https://doi.org/10.1017/jmo.2014.71

Breevaart, K., Bakker, A. B., Demerouti, E., \& Derks, D. (2016). Who takes the lead? A multi-source diary study on leadership, work engagement, and job performance. Journal of Organizational Behavior, 37, 309-325. https://doi.org/10.1002/job.2041

Caesens, G., \& Stinglhamber, F. (2014). The relationship between perceived organizational support and work engagement: The role of self-efficacy and its outcomes. European Review of Applied Psychology / Revue Européenne de Psychologie Appliquée, 64(5), 259-267. http://dx.doi.org/10.1016/j.erap.2014.08.002

Carasco-Saul, M., Kim, W., \& Kim, T. (2015). Leadership and Employee Engagement: Proposing Research Agendas through a Review of Literature, Human Resource Development Review, 14(1), 38-63. https://doi.org/10.1177/1534484314560406

Corin, L., \& Björk, L. (2016). Job Demands and Job Resources in Human Service Managerial Work - An External Assessment through Work Content Analysis. Nordic Journal of Working Life Studies, 6(4), 3-28. https://doi.org/10.19154/njwls.v6i4.5610

Cobzaru, A. (2010). Work engagement among employees in private universities. Vigor. Dedication. Absorption. Quality Management in Higher Education, 2, 35-38. 
Dimitrov, D. (2015). Leadership in a humane organization. European Journal of Training and Development, $39(2), 122-142$. https://doi.org/10.1108/EJTD-07-2014-0051

Duyar, I., \& Normore, A. (2012). Discretionary Behavior and Performance in Educational Organizations: The Missing Link in Educational Leadership and Management. Advances in Educational Administration, 13, Emerald Group Publishing Limited, Bingley, 331-338. https://doi.org/10.1108/S1479-3660(2012)0000013018

Eldor, L. (2017). Looking on the bright side: The positive role of organizational politics in the relationship between employee engagement and performance at work. Applied Psychology: An International Review, 66(2), 233-259. http://dx.doi.org/10.1111/apps.12090

Enwereuzor, I. K., Ugwu, L. I., \& Eze, O. A. (2018). How Transformational Leadership Influences Work Engagement Among Nurses: Does Person-Job Fit Matter? Western Journal of Nursing Research, 40(3) 346-366. https://doi.org/10.1177/0193945916682449

Engelbrecht, A. S., Heine, G., \& Mahembe, B. (2016). Integrity, ethical leadership, trust and work engagement. Journal of Managerial Psychology, 28(2), 133-146. https://doi.org/10.1108/LODJ-11-2015-0237

Eslami, J., \& Gharakhani, D. (2012). Organizational commitment and job satisfaction. Journal of Science and Technology, 2(2), 8591.

Ghadi, M. Y., Fernando, M., \& Caputi, P. (2013). Transformational leadership and work engagement the mediating effect of meaning in work. Leadership \& Organization Development Journal, 34 (6), 532-550. https://doi.org/10.1108/LODJ-10-2011-0110

Ghafoor, A., Qureshi, T. M., Khan, M. A., \& Hijazi, S. T. (2011). Transformational leadership, employee engagement and performance: Mediating effect of psychological ownership, African Journal of Business Management, 5(17), 7391-7403. https://doi.org/10.5897/AJBM11.126

Gillet, N., Becker, C., Lafrenière, M.-A., Huart, I., \& Fouquereau, E. (2017). Organizational support, job resources, soldiers' motivational profiles, work engagement, and affect. Military Psychology, 29(5), 418-433. http://dx.doi.org/10.1037/mil0000179

Giray, M. D., \& Şahin, D. N. (2014). Perceived organizational support as a mediator of the relationship between leadership styles and organizational outcomes. Türk Psikoloji Dergisi, 29(73), 1-17.

Goswami, A., Nair, P., Beehr, T., \& Grossenbacher, M. (2016). The relationship of leaders' humor and employees' work engagement mediated by positive emotions Moderating effect of leaders' transformational leadership style. Leadership \& Organization Development Journal, 37 (8), 1083-1099. https://doi.org/ 10.1108/LODJ0120150001

Gözükaraa, I., \& Simsek, O. F. (2015). Linking Transformational Leadership to Work Engagement and the Mediator Effect of Job Autonomy: A Study in a Turkish Private Non-Profit University. Social and Behavioral Sciences, 195, 963-971. https://doi.org/10.1016/j.sbspro.2015.06.274

Hanson, D., \& Ward, C. (2010). Staff engagement in the Singaporean school system: leadership training strategies for the development of Singapore school principals. International conference on education and new learning technologies, JUL 2010. Barcelona, SPAIN.

Harris, T. B., Li, N., Boswell, W. R., Zhang, X. A., \& Xie, Z. (2014). Getting what's new from newcomers: Empowering leadership, creativity, and adjustment in the socialization context. Personnel Psychology, 67(3), 567-604. https://doi.org/10.1111/peps.12053

Hayati, D., Charkhabi, M., \& Naami, A. Z. (2014). The relationship between transformational leadership and work engagement in governmental hospitals nurses: a survey study. SpringerPlus, 3(25), 2-7. https://doi.org/10.1186/2193-1801-3-25.

Hempfling, M. S. (2017). Happiness, work engagement, and perception of organizational support of student affairs professionals. Dissertation Abstracts International Section A: Humanities and Social Sciences, 77(7-A(E)).

Henker, N., Sonnentag, S., \& Unger, D. (2015). Transformational leadership and employee creativity. Journal of Business and Psychology, 30, 235-247. https://doi.org/10.1007/s10869-014-9348

Hsieh, C. C., \& Wang, D. S. (2015). Does supervisor perceived authentic leadership influence employee work engagement through employee perceived authentic leadership and employee trust? International Journal of Human Resource Management, 26(18), 2329-2348. https://doi.org/10.1080/09585192.2015.1025234 Published

Jaime, M. M. M., Gallo, L. A., \& Caraveo, M. E. M. (2012). Mental health integrity of clinical staff at a psychiatric hospital, associated to burn-out and toxic management. Salud Mental, 35(4), 297-304.

Jeong, S., Hsiao, Y. Y., Song, J. H., Kim, J., \& Bae, S. H. (2016). The Moderating Role of Transformational Leadership on Work Engagement: The Influences of Professionalism and Openness to Change. Human Resource Development Quarterly, 27(4), 489-516. https://doi.org/10.1002/hrdq.21265

Korzynski, P. (2015). Online networking and employee engagement: what current leaders do? Journal of Managerial Psychology, 30 (5), 582-596. https://doi.org/10.1108/jmp-10-2013-0344

Lee, M. C. C., Idris, M. A., \& Delfabbro, P. H. (2017). The linkages between hierarchical culture and empowering leadership and their effects on employees' work engagement: Work meaningfulness as a mediator. International. Journal of Stress Management, 24(4), 392-415. http://dx.doi.org/10.1037/str0000043

Lewis, H. S., \& Cunningham, C. J. (2016). Linking Nurse Leadership and Work Characteristics to Nurse Burnout and Engagement. Nurs Res, 65(1),13-23. https://doi.org/10.1097/NNR.0000000000000130. 
Manning, J. M. (2016). The Influence of Nurse Manager Leadership Style Factors on the Perception of Staff nurse Structural Empowerment, Work Engagement, and Intent to Stay (Doctoral dissertation). Available from PsycINFO Database Record (c) 2016 APA.

Markos, S., \& Sridevi, M. S. (2010). Employee Engagement: The Key to Improving Performance. International Journal of Business and Management, 5, 89-96. https://doi.org/10.5539/ijbm.v5n12p89

Meng, Y. S., \& Xiao, J. J. (2015). Study on the Influence of Spiritual Leadership on Hospitality Industry Employee Engagement. Proceedings of the 11th Euro Asia Conference on Environment and CSR: Tourism, Society and Education Session (Part II) 96-105.

Mitonga-Monga, J., \& Hlongwane, V. (2017). Effects of employees' sense of coherence on leadership style and work engagement. Journal of Psychology in Africa, 27(4), 351-355. https://doi.org/10.1080/14330237.2017.1347757

Moumen, M., \& El Aoufir, H. (2017). Quality, safety and environment management systems (QSE): analysis of empirical studies on integrated management systems (IMS). Journal of Decision Systems, 26(3), 207-228. https://doi.org/10.1080/12460125.2017.1305648

$\mathrm{Ni}$, N. J. (2016). The relationship among leadership style, employees' engagement and management performance in Grid Company. International Conference on Applied Mechanics, Electronics and Mechatronics Engineering, 2016. Beijing, PEOPLES R CHINA.

Noordin, F., \& Jusoff, K. (2009). Levels of job satisfaction amongst Malaysian Academic Staff. Journal of Asian Social Science, 5(5), 122-128. https://doi.org/10.5539/ass.v5n5p122

Popli, S., \& Rizvi, I. A. (2015). Exploring the relationship between service orientation, employee engagement and perceived leadership style: a study of managers in the private service sector organizations in India. Journal of Services Marketing, 29(1), 59-70. https://doi.org/ 10.1108/JSM0620130151.

Saleem, H. (2015). The impact of leadership styles on job satisfaction and mediating role of perceived organizational politics. Social and Behavioral Sciences, 172, 563 -569. https://doi.org/10.1016/j.sbspro.2015.01.403

Schmitt, A., Den Hartog, D. N., \& Belschak, F. D. (2016). Transformational leadership and proactive work behaviour: A moderated mediation model including work engagement and job strain. Journal of Occupational and Organizational Psychology, 89(3), 588-610. https://doi.org/10.1111/joop.12143

Shantz, A., Alfes, K., \& Latham, G. P. (2016). The buffering effect of perceived organizational support on the relationship between work engagement and behavioral outcomes. Human Resource Management, 55(1), 25-38. https://doi.org/10.1002/hrm.21653

Strom, D. L., Sears, K. L., \& Kelly, K. M. (2014). Work engagement: The roles of organizational justice and leadership style in predicting engagement among employees. Journal of Leadership \& Organizational Studies, 21(1), 71-82. http://dx.doi.org/10.1177/1548051813485437

Wang, Z. (2015). Reaping benefits employee proactive personality: Roles of team proactivity composition, perceived organizational support, and work engagement. Dissertation Abstracts International: Section B: The Sciences and Engineering, 75(9-B(E)).

Yongxing, G., Hongfei, D., Baoguo, X., \& Lei, M. (2017). Work engagement and job performance: The moderating role of perceived organizational support. Anales de Psicología, 33(3), 708-713. https://doi.org/10.6018/analesps.33.3.238571Zacher, H., \& Winter, G. (2011). Eldercare demands, strain, and work engagement: The moderating role of perceived organizational support. Journal of Vocational Behavior, 79(3), 667-680. https://doi.org/10.1016/j.jvb.2011.03.020

Zacher, H., \& Winter, G. (2011). Eldercare demands, strain, and work engagement: The moderating role of perceived organizational support. Journal of Vocational Behavior, 79(3), 667-680. https://doi.org/10.1016/j.jvb.2011.03.020

Zhang, X. M., \& Bartol, K. M. (2011). Linking empowering leadership and employee creativity: the influence of psychological empowerment, intrinsic motivation, and creative process engagement, Academy of Management Journal, 53 (1), 107-128. http://dx.doi.org/10.5465/AMJ.2010.48037118

Zhu, W., Avolio, B. J., \& Walumbwa, F. O. (2016). Moderating role of follower characteristics with transformational leadership and follower work engagement. Group \& Organization Management, 41(3), 407-409. https://doi.org/10.1177/1059601108331242

Zone, E. J. (2014). The relationship of perceived organizational support, job satisfaction, and years of online teaching experience to work engagement among online undergraduate adjunct faculty members. Dissertation Abstracts International Section A: Humanities and Social Sciences, 74(10-A(E)).

Xinxin, L., X., Baoguo , X., \& Yongxing, G. (2018). The trickle-down of work engagement from leader to follower: The roles of optimism and self-efficacy. Journal of Business Research, 48, 186-195. https://doi.org/10.1016/j.jbusres.2017.11.014

Xiang, H., Chen, Y., \& Zhao, F. (2017). Inclusive Leadership, Perceived Organizational Support, and Work Engagement: The Moderating Role of Leadership-Member Exchange Relationship, 7th International Conference on Social Network, Communication and Education (SNCE), Shenyang, Peoples r china, jul 28-30, 2017. Acsr-Advances in Computer Science Rese. 